\title{
Proteocatella sphenisci gen. nov., sp. nov., a psychrotolerant, spore-forming anaerobe isolated from penguin guano
}

\author{
Correspondence \\ Elena V. Pikuta \\ elena.pikuta@uah.edu
}

\author{
Elena V. Pikuta, ${ }^{1}$ Richard B. Hoover, ${ }^{1}$ Damien Marsic, ${ }^{2}$ \\ William B. Whitman, ${ }^{3}$ Boguslaw Lupa, ${ }^{3}$ Jane Tang $^{4}$ and Paul Krader ${ }^{4}$ \\ ${ }^{1}$ NASA/NSSTC, Astrobiology Laboratory, 320 Sparkman Drive, Room 4247, Huntsville, AL 35805, \\ USA \\ ${ }^{2}$ Laboratory for Structural Biology, The University of Alabama in Huntsville, MSB, Huntsville, \\ AL 35899, USA \\ ${ }^{3}$ Department of Microbiology, University of Georgia, Athens, GA 30602-2605, USA \\ ${ }^{4}$ American Type Culture Collection, 10801 University Blvd, Manassas, VA 20110, USA
}

Microbiological investigations of penguin guano collected in Chilean Patagonia led to the isolation of two anaerobic bacterial strains capable of growth at low temperatures (Hoover et al., 2002). One of these strains, $\mathrm{PmagG1}^{\mathrm{T}}$, was identified as a psychrotolerant, saccharolytic bacterium that was capable of growth at $-5{ }^{\circ} \mathrm{C}$, and was subsequently described as representing a novel species, Trichococcus patagoniensis (Pikuta et al., 2006). The second strain, designated $\mathrm{PPP} 2^{\mathrm{T}}$, was a Gram-positive, spore-forming proteolytic anaerobe that did not show an ability to grow at subzero temperatures (Pikuta et al., 2003; Pikuta \& Hoover, 2003, 2004). Phylogenetic analysis showed that

The GenBank/EMBL/DDBJ accession number for the 16S rRNA gene sequence of strain PPP2 ${ }^{\top}$ is AF450134.

A figure showing the temperature range and optimum for growth of strain $P P P 2^{\top}$ and a table giving the fatty acid composition of strain ${ }^{P P P 2}{ }^{\top}$ are available as supplementary material with the online version of this paper. strain $\mathrm{PPP}^{\mathrm{T}}$ was only very distantly related to any recognized species (Pikuta et al., 2003). Its closest neighbour on the phylogenetic tree, Clostridium sticklandii SR, shared only $91.3 \% 16 \mathrm{~S}$ rRNA gene sequence similarity. Phenotypically, the novel isolate was mesophilic and psychrotolerant, did not require $\mathrm{NaCl}$ for growth, was neutrophilic and alkalitolerant, and showed obligately anaerobic metabolism. It was a fermentative proteolytic bacterium that was able to use various products of proteolysis as substrates, but not sugars. The present article provides a detailed taxonomic description of strain $\mathrm{PPP} 2^{\mathrm{T}}$, and shows that it represents a novel species of a new genus within the family Clostridiaceae.

Strain $\mathrm{PPP} 2^{\mathrm{T}}$ was isolated from a sample of guano of the Magellanic penguin (Spheniscus magellanicus) in Chilean Patagonia. Detailed descriptions of the sampling procedure and transportation to the laboratory are given in Pikuta et al. (2006). 
An enrichment culture was obtained anaerobically on medium comprising (per litre): $30.0 \mathrm{~g} \mathrm{NaCl}, 0.3 \mathrm{~g} \mathrm{KCl}$, $0.3 \mathrm{~g} \mathrm{KH}_{2} \mathrm{PO}_{4}, 0.1 \mathrm{~g} \mathrm{MgCl}_{2} .6 \mathrm{H}_{2} \mathrm{O}, 1.0 \mathrm{~g} \mathrm{NH}_{4} \mathrm{Cl}, 0.0125 \mathrm{~g}$ $\mathrm{CaSO}_{4} .7 \mathrm{H}_{2} \mathrm{O}, 0.2 \mathrm{~g} \mathrm{NaHCO}_{3}, 0.4 \mathrm{~g} \mathrm{Na}_{2} \mathrm{~S} .9 \mathrm{H}_{2} \mathrm{O}, 0.001 \mathrm{~g}$ resazurin, $0.2 \mathrm{~g}$ yeast extract, $3.0 \mathrm{~g}$ peptone, $2 \mathrm{ml}$ vitamin solution (Wolin et al., 1963) and $1 \mathrm{ml}$ trace mineral solution [containing (per $500 \mathrm{ml}$ ): $392 \mathrm{mg}\left(\mathrm{NH}_{4}\right)_{2} \mathrm{SO}_{4}$. $\mathrm{FeSO}_{4} \cdot 6 \mathrm{H}_{2} \mathrm{O}$, $119 \mathrm{mg} \mathrm{CoCl} .6 \mathrm{H}_{2} \mathrm{O}, 65.16 \mathrm{mg} \mathrm{NiCl}, 12.1 \mathrm{mg} \mathrm{Na} \mathrm{MoO}_{4}$, $16.5 \mathrm{mg} \mathrm{Na} \mathrm{WO}_{4} .2 \mathrm{H}_{2} \mathrm{O}, 71.8 \mathrm{mg} \mathrm{ZnSO}_{4} .7 \mathrm{H}_{2} \mathrm{O}, 101 \mathrm{mg}$ $\mathrm{CuSO}_{4} .5 \mathrm{H}_{2} \mathrm{O}, 43.7 \mathrm{mg} \mathrm{Na} \mathrm{SeO}_{4}, 3.1 \mathrm{mg} \mathrm{H}_{3} \mathrm{BO}_{3}, 49.5 \mathrm{mg}$ $\mathrm{MnCl}_{2} \cdot 4 \mathrm{H}_{2} \mathrm{O}$ and $5 \mathrm{ml} \mathrm{HCl}$. Final $\mathrm{pH}$ of the medium was 7.1-7.2. High-purity nitrogen was used as the gas phase. A homogeneous sample $(0.5 \mathrm{~g})$ was injected into a Hungate tube, containing an anaerobic medium, and incubated for 7 10 days at $2{ }^{\circ} \mathrm{C}$. A pure culture was obtained by serial dilution in Hungate tubes and was supported on the medium described above except that the $\mathrm{NaCl}$ concentration was reduced to $0.5 \%(\mathrm{w} / \mathrm{v})$. The eighth dilution of a morphologically monotypic culture exhibiting growth at $2{ }^{\circ} \mathrm{C}$ on peptone-containing medium was chosen for inoculation on agar medium for growth of colonies.

Isolation of colonies was performed by the roll-tube method on $3 \%(\mathrm{w} / \mathrm{v})$ agar medium. After 7-10 days cultivation on agar medium at $2{ }^{\circ} \mathrm{C}$, colonies of strain $\mathrm{PPP} 2^{\mathrm{T}}$ were creamy yellow and rounded lens-shaped with a diameter of 1-2 mm. Young colonies were white. Colonies had a rough surface and central conical protuberance. Edges of the colonies were thin and smooth, and the centre of the colonies had a denser consistency and darker colour. Purification of strain $\mathrm{PPP}^{\mathrm{T}}$ was performed at $2{ }^{\circ} \mathrm{C}$. Experiments with the pure culture were performed at 6$22{ }^{\circ} \mathrm{C}$. Purity of the culture was determined based on negative growth on D-glucose medium at room temperature and by microscope observation.

The morphology of the new isolate was examined under a phase-contrast microscope (Fisher Micromaster) and FEI Tecnai 20 transmission electron microscope (FEI Co.) at $200 \mathrm{kV}$ with attached digital camera. Cells of strain PPP2 $2^{\mathrm{T}}$ were rod-shaped, with a diameter of $0.7-0.8 \mu \mathrm{m}$ and length of $3-5 \mu \mathrm{m}$ (Fig. 1a). Cells were motile by means of peritrichous flagella (Fig. 1b). For transmission electron microscopy, cells were concentrated by centrifugation, resuspended in $50 \mathrm{mM}$ cacodylate buffer, $50 \mathrm{mM} \mathrm{NaCl}$, $\mathrm{pH} 8.3$, and then fixed with $2 \%$ glutaraldehyde for $20 \mathrm{~min}$ at room temperature and negatively stained with $2 \%$ uranyl acetate for 10-60 s.

Gram staining of cell membranes revealed a blue colour, typical of Gram-positive bacteria. Large, circular spores with a diameter twice the cell diameter were located at the end of cells (terminal position). Cells occurred singly, in pairs or in short, irregularly curved chains. Cell division occurred by fission, sometimes unequally with the formation of terminally rounded mini-cells.

Growth was determined based on cell counts with the phase-contrast microscope or by measuring the optical density at $595 \mathrm{~nm}$ (Genesis 5; Spectronic Instruments).

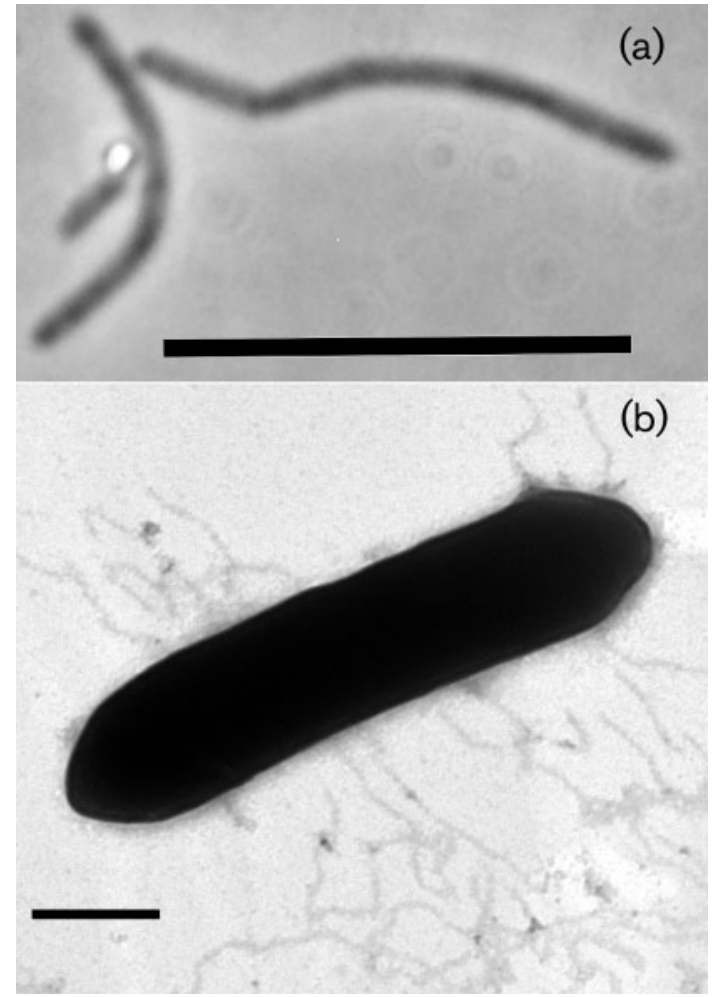

Fig. 1. (a) Phase-contrast micrograph of live culture showing the morphology of cells of strain $\mathrm{PPP} 2^{\top}$ and a spore within the sporangium. Bar, $10 \mu \mathrm{m}$. (b) Transmission electron micrograph of a cell of strain PPP2 ${ }^{\top}$ with peritrichous flagella. Bar, $500 \mathrm{~nm}$.

Catalase activity was determined based on the reaction with hydrogen peroxide (Gerhardt et al., 1994). All test substrates $\left(3 \mathrm{~g} \mathrm{l}^{-1}\right)$ were added to medium containing $0.1 \mathrm{~g}$ yeast extract. End products of peptone fermentation in the liquid phase were determined by HPLC. Separation was done on an Aminex HPX-87H (Bio-Rad) column with $5 \mathrm{mM} \mathrm{H}_{2} \mathrm{SO}_{4}$ as the mobile phase. Gases were measured via a Varian 3700 gas chromatograph equipped with a Porapak Q column and thermal conductivity detector. Nitrogen was used as the carrier gas.

Strain $\mathrm{PPP}^{\mathrm{T}}$ grew only under strictly anaerobic conditions. It was catalase-negative. Growth was observed at 0 $4 \%(\mathrm{w} / \mathrm{v}) \mathrm{NaCl}$, with optimum growth at $0.5 \%$; no growth occurred at $5 \% \mathrm{NaCl}$. The $\mathrm{pH}$ range for growth was $6.7-$ 9.7 with optimum growth at $\mathrm{pH}$ 8.3. The new isolate was a psychrotolerant mesophile, growing between 2 and $37^{\circ} \mathrm{C}$ with optimum growth at $29{ }^{\circ} \mathrm{C}$ (Supplementary Fig. S1, available in IJSEM Online).

Strain $\mathrm{PPP}^{\mathrm{T}}$ possessed a chemo-organoheterotrophic metabolism and was able to grow on the following substrates: peptone, bacto-tryptone, Casamino acids, yeast extract, starch, chitin and oxalate. Growth on starch and chitin was weak (three or four cells per field) on all three transfers for each substrate. No growth was observed on 
formate, acetate, lactate, pyruvate, propionate, butyrate, citrate, methanol, ethanol, glycerol, acetone, D-mannitol, D-glucose, D-fructose, D-ribose, trehalose, D-arabinose, maltose, D-mannose, lactose, sucrose, cellobiose, pectin, $\mathrm{N}$-acetylglucosamine, urea, trimethylamine, triethylamine or betaine. Separate amino acids on mineral medium supplemented with yeast extract $\left(0.1 \mathrm{~g} \mathrm{l}^{-1}\right)$ did not support growth of strain PPP2 $2^{\mathrm{T}}$. No growth occurred on L-cysteine, L-cystine, L- or D-methionine, L- or Dproline, L- or D-lysine, L- or D-serine, L- or D-arginine, L-tyrosine, glycine, trans-4-hydroxy-L-proline, L- or Dhistidine hydrochloride, L-glutamine, L- or D-aspartic acid, L- or D-leucine, L- or D-tryptophan, L- or D-valine, L- or Dalanine, L-glutamic acid, L-phenylalanine, L-isoleucine, Lor D-threonine or L-asparagine.

Interestingly, strain $\mathrm{PPP} 2^{\mathrm{T}}$ grew on sodium oxalate only in medium supplemented with selenium as a trace element. Cell morphology of strain $\mathrm{PPP}^{\mathrm{T}}$ on this substrate was atypical, with a tendency for the cells to appear swollen and with a hexagonal crystalline shape (data not shown).

The Stickland reaction was negative for the following combinations of amino acids: L-proline $+\mathrm{L}$-leucine, Lproline $+\mathrm{L}$-isoleucine, L-proline $+\mathrm{L}$-valine, $\mathrm{L}$-proline + $\mathrm{L}$-alanine, glycine $+\mathrm{L}$-leucine, glycine $+\mathrm{L}$-isoleucine, glycine + L-valine, glycine $+\mathrm{L}$-alanine and L-tryptophan $+\mathrm{L}$-valine.

Two gaseous metabolic products of the culture grown on peptone-containing medium were $\mathrm{CO}_{2}$ and $\mathrm{H}_{2}$ (both in trace quantities, $<1 \%)$. In the liquid phase, acetate $(21 \mathrm{mM})$, ethanol $(4.3 \mathrm{mM})$ and butyrate $(5 \mathrm{mM})$ were found.

Antibiotic resistance was tested by using the following: ampicillin, kanamycin, gentamicin, vancomycin, tetracycline, rifampicin $\left(250 \mu \mathrm{g} \mathrm{ml}^{-1}\right)$ and chloramphenicol $\left(125 \mu \mathrm{g} \mathrm{ml}^{-1}\right)$. Strain PPP2 ${ }^{\mathrm{T}}$ was sensitive to kanamycin, gentamicin, tetracycline, rifampicin, vancomycin and chloramphenicol, but was resistant to ampicillin.

Fatty acid methyl esters (FAMEs) were extracted from fresh biomass incubated for 4 days at $22{ }^{\circ} \mathrm{C}$ and were identified following the procedure recommended by the Microbial Identification System (MIDI Inc.) anaerobic Moore Library. The extraction procedure included sonication, methylation, organic extraction (transfer of FAMEs from an aqueous phase to an organic phase) and a base wash; cell extracts were then analysed by GC (Sherlock Microbial Identification System version 4.0; MIDI Inc.). The predominant FAMEs of strain $\mathrm{PPP}^{\mathrm{T}}$ were $\mathrm{C}_{14: 0}$ (15.11\% of the total), $\mathrm{C}_{16: 0}(13.97 \%)$ and dimethyl aldehyde $\mathrm{C}_{18: 1}$ cis11 (12.74\%) (Supplementary Table S1).

The $\mathrm{G}+\mathrm{C}$ content of the genomic DNA of strain $\mathrm{PPP}^{\mathrm{T}}$ was measured by HPLC as described by Mesbah et al. (1989) except that an Alltima C18 column $(250 \mathrm{~mm} \times 4.6 \mathrm{~mm}, 5$ $\mu \mathrm{m}$ particle size; Alltech) and $8 \%(\mathrm{v} / \mathrm{v})$ methanol were used. The results reported are means $\pm \mathrm{SD}$ of two determinations for each of two DNA degradations. The $\mathrm{G}+\mathrm{C}$ content of the genomic DNA of strain $\mathrm{PPP}^{\mathrm{T}}$ was $39.5 \pm 0.2 \mathrm{~mol} \%(n=4)$.
Isolation of genomic DNA, amplification of the $16 \mathrm{~S}$ rRNA gene and sequence determination were performed as described by Hoover et al. (2003). The consensus sequence was assembled by using sequence data from four different clones. The $16 \mathrm{~S}$ rRNA gene sequence obtained was aligned with 21 similar sequences selected from a BLAST search (Altschul et al., 1990) via the GenBank database. Alignment was performed by using the CLUSTAL $\mathrm{W}$ program (Thompson et al., 1994). Pairwise distances were computed with MEGA version 4 (Tamura et al., 2007) by using the Jukes-Cantor model (Jukes \& Cantor, 1969). An unrooted phylogenetic tree was constructed with the same program according to the neighbour-joining method (Saitou \& Nei, 1987). Sites with gaps in any sequence of the alignment were excluded from all analyses.

A sequence covering $1450 \mathrm{nt}$ of the $16 \mathrm{~S}$ rRNA gene of strain PPP $2^{\mathrm{T}}$ was obtained, corresponding to positions $27-$ 1492 of the Escherichia coli 16S rRNA gene sequence. The $\mathrm{G}+\mathrm{C}$ content of this gene sequence was $53.59 \mathrm{~mol} \%$. A comparison with all sequences available in the GenBank database revealed over $80 \%$ similarity with sequences from the genera Clostridium, Sporacetigenium, Eubacterium, Peptostreptococcus, Filifactor, Alkaliphilus, Geosporobacter, Acidaminobacter and Fusibacter. Although the phylogenetic dendrogram, based on 1265 common nucleotide positions (Fig. 2), showed strain $\mathrm{PPP}^{\mathrm{T}}$ to be related most closely to members of the genus Filifactor, highest 16S rRNA gene sequence similarity was observed with Clostridium sticklandii SR (91.3\% within the 1265 sites used for the tree and $89.4 \%$ over a 1450 -nt global alignment).

Strain $\mathrm{PPP}^{\mathrm{T}}$ was isolated from an alkaline sample of Magellanic penguin guano. The fact that Magellanic penguins are endemic to the southern tip of South America, a region with a very cold climate, is reflected in the physiological characteristics of strain $\mathrm{PPP}^{\mathrm{T}}$ : the strain showed tolerance to low temperature (down to $2{ }^{\circ} \mathrm{C}$ ), high $\mathrm{pH}$ and marine concentrations of $\mathrm{NaCl}$. All these environmental factors have had an influence on the phenotype of strain $\mathrm{PPP} 2^{\mathrm{T}}$, probably as a result of the adaptive flexibility of its genome. The ability of the new isolate to use exclusively products of proteolysis and oxalate (but not sugars) is probably due to the restricted diet of these penguins: they feed on marine fish and crustaceans.

It is of note that strain $\mathrm{PPP} 2^{\mathrm{T}}$ is resistant to ampicillin, a characteristic that is extremely rare in environmental bacterial strains. The closest phylogenetic neighbour to strain $\mathrm{PPP} 2^{\mathrm{T}}$ based on $16 \mathrm{~S}$ rRNA gene sequences was $C$. sticklandii SR, but with $\sim 10 \%$ sequence divergence, and therefore phenotypic comparisons with other recognized species were unnecessary. Strain $\mathrm{PPP}^{\mathrm{T}}$ showed phenotypic features typical of the family Clostridiales: strictly anaerobic growth, spore formation, Gram-positive cell walls, fermentative metabolism and acetogenesis. Table 1 shows distinguishing features between strain $\mathrm{PPP}^{\mathrm{T}}$ and recognized mesophilic, anaerobic, acetogenic genera of the family Clostridiales. 


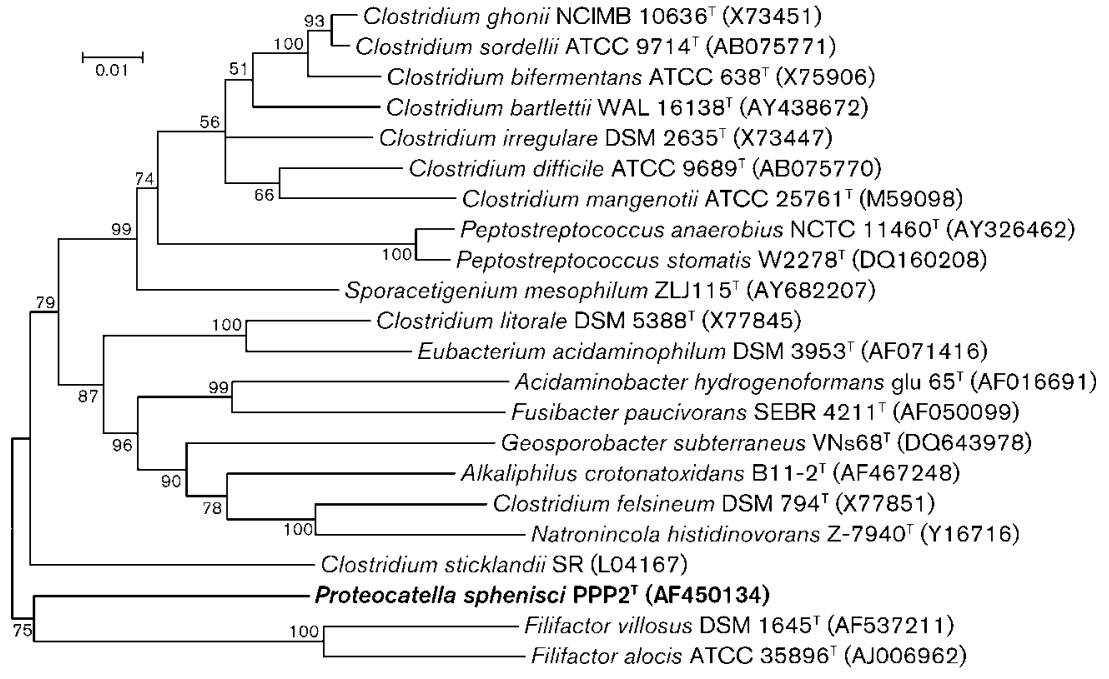

Fig. 2. Unrooted neighbour-joining phylogenetic tree based on 16S rRNA gene sequences, showing the position of strain PPP2 ${ }^{\top}$ among its closest neighbours. Numbers at nodes are bootstrap percentages based on 2000 replications. Accession numbers are given in parentheses. Bar, 1 substitution per 100 nucleotide positions.
Based on its phenotypic and genotypic characteristics (Gram-positive cell wall, spore formation, obligately anaerobic and fermentative metabolism, mesophilic/psychrotolerant and neutrophilic/alkalitolerant physiology, no $\mathrm{NaCl}$ requirement for growth, fatty acid profile and $16 \mathrm{~S}$ rRNA gene sequence), strain $\mathrm{PPP}^{\mathrm{T}}$ is considered to represent a novel species of a new genus, for which the name Proteocatella sphenisci gen. nov., sp. nov. is proposed.

\section{Description of Proteocatella gen. nov.}

Proteocatella (Pro'te.o.ca.tel'la. N.L. n. proteinum protein; N.L. pref. proteo- prefix referring to protein used in compound words; L. fem. n. catella small chain; N.L. fem. n. Proteocatella a small chain using proteins).

Mesophilic, spore-forming, fermentative rods with Grampositive cell-wall structure. Obligate anaerobes. Alkalitolerant.

Table 1. Differential characteristics between strain $P P P 2^{\top}$ and related anaerobic, mesophilic, acetogenic genera within the family Clostridiaceae

Taxa: 1, strain $\mathrm{PPP}^{\mathrm{T}}$; 2, Clostridium (data from Hippe et al., 1992); 3, Sporacetigenium (Chen et al., 2006); 4, Eubacterium (Andreesen, 1992); 5, Filifactor (Collins et al., 1994; Love et al., 1979); 6, Alkaliphilus (Takai et al., 2001; Cao et al., 2003); 7, Geosporobacter (Klouche et al., 2007); 8, Fusibacter (Ravot et al., 1999); 9, Acidaminobacter (Stams \& Hansen, 1984); 10, Tissierella (Collins \& Shah, 1986; Farrow et al., 1995; Bae et al., 2004); 11, Natronincola (Zhilina et al., 1998); 12, Tindallia (Kevbrin et al., 1998). ND, No data; +, positive; -, negative; +/-, variable.

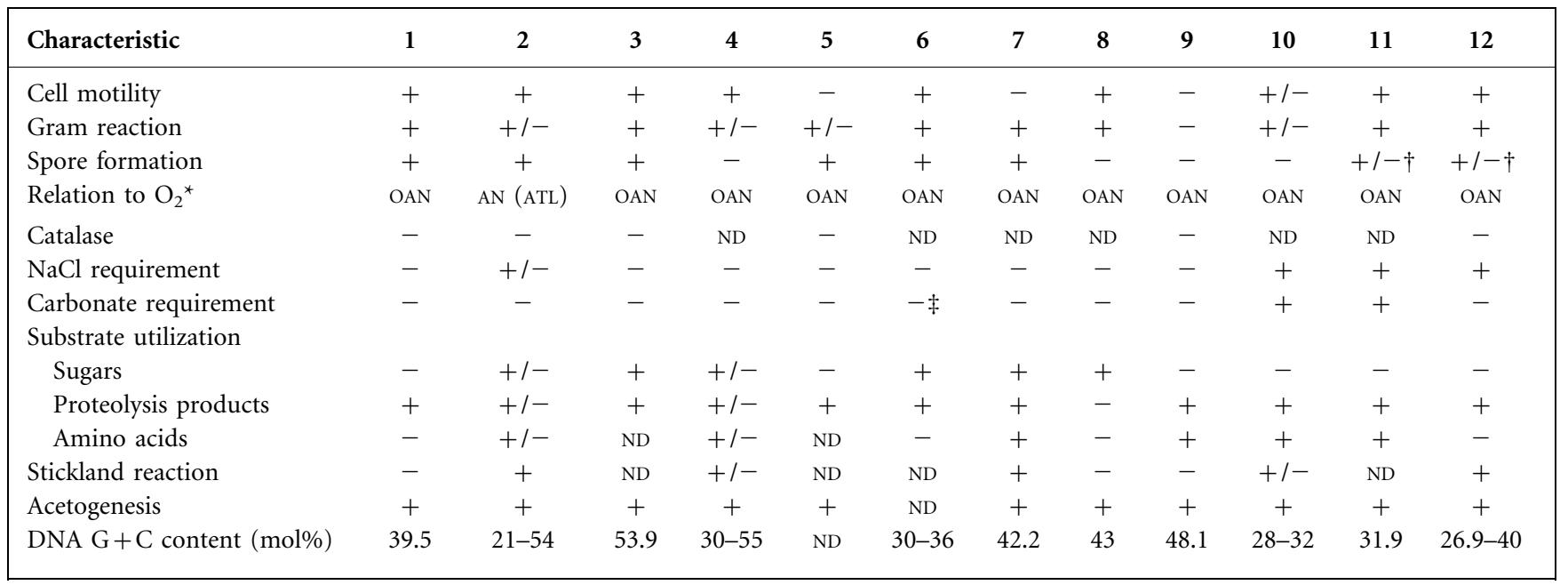

${ }^{*}$ AN (ATL), Aerotolerant anaerobe; OAN, obligate anaerobe.

†Oligospore-forming.

$\ddagger$ K. Takai, personal communication. 
Do not require carbonate ions or $\mathrm{NaCl}$ for growth. Psychrotolerant mesophiles. Acetogenic (producing acetate as major end product). The type species is Proteocatella sphenisci.

\section{Description of Proteocatella sphenisci sp. nov.}

Proteocatella sphenisci (sphe.nis'ci. N.L. gen. n. sphenisci of Spheniscus, zoological name of a genus of penguin, referring to the isolation of the type strain from guano of Spheniscus magellanicus, the Magellanic penguin).

Has the following characteristics in addition to those given for the genus above. Cells are flexible, motile rods, 0.7$0.8 \times 3.0-5.0 \mu \mathrm{m}$, that tend to form long chains. Multiplies by fission, sometimes unequally with the formation of terminally round mini-cells. Motile by means of flagella. Spores are spherical. Sporangium is not swollen. Grows at $2-37{ }^{\circ} \mathrm{C}$ (optimum $29{ }^{\circ} \mathrm{C}$ ) and at $\mathrm{pH}$ 6.7-9.7 (at $22{ }^{\circ} \mathrm{C}$ ) (optimum $\mathrm{pH} 8.3)$. $\mathrm{NaCl}$ range for growth is $0-4 \%(\mathrm{w} / \mathrm{v})$; optimal growth at $0.5 \%(\mathrm{w} / \mathrm{v}) \mathrm{NaCl}$. Catalase-negative. Heterotrophic growth with peptone, bacto-tryptone, Casamino acids, oxalate, starch, chitin and yeast extract. End products of peptone fermentation are acetate, butyrate and ethanol and, in the gas phase, minor products are hydrogen and carbon dioxide. Resistant to ampicillin, but sensitive to kanamycin, gentamicin, tetracycline, rifampicin, vancomycin and chloramphenicol. The $\mathrm{G}+\mathrm{C}$ content of the genomic DNA of the type strain is $39.5 \mathrm{~mol} \%$ (HPLC).

The type strain, PPP $2^{\mathrm{T}}\left(=\mathrm{ATCC}\right.$ BAA $-755^{\mathrm{T}}=\mathrm{JCM} 12175^{\mathrm{T}}$ $=$ CIP $108034^{\mathrm{T}}$ ), was isolated from guano of Magellanic penguins (Spheniscus magellanicus) inhabiting the coast of Chilean Patagonia.

\section{Acknowledgements}

We are grateful to Dr Vadim V. Kevbrin and Professor J. Wiegel (University of Georgia, Athens) for assistance in measuring end products, and for access to phase-contrast microscopy. We wish to acknowledge the NASA JSC Astrobiology Institute for Biomarkers in Astromaterials for financial support.

\section{References}

Altschul, S. F., Gish, W., Miller, W., Myers, E. W. \& Lipman, D. J. (1990). Basic local alignment search tool. J Mol Biol 215, 403-410.

Andreesen, J. R. (1992). The genus Eubacterium. In The Prokaryotes, 2nd edn, vol. 2, pp. 1914-1924. Edited by A. Balows, H. G. Trüper, M. Dworkin, W. Harder \& K. H. Schleifer. New York: Springer.

Bae, J.-W., Park, J. R., Chang, Y.-H., Rhee, S.-K., Kim, B.-C. \& Park, Y.-H. (2004). Clostridium hastiforme is a later synonym of Tissierella praeacuta. Int J Syst Evol Microbiol 54, 947-949.

Cao, X., Liu, X. \& Dong, X. (2003). Alkaliphilus crotonatoxidans sp. nov., a strictly anaerobic, crotonate-dismutating bacterium isolated from a methanogenic environment. Int J Syst Evol Microbiol 53, 971975.

Chen, S., Song, L. \& Dong, X. (2006). Sporacetigenium mesophilum gen. nov., sp. nov., isolated from an anaerobic digester treating municipal solid waste and sewage. Int J Syst Evol Microbiol 56, 721725.

Collins, M. D. \& Shah, H. N. (1986). Reclassification of Bacteroides praecutus Tissier (Holdeman and Moore) in a new genus, Tissierella, as Tissierella praeacuta comb. nov. Int J Syst Bacteriol 36, 461-463.

Collins, M. D., Lawson, P. A., Willems, A., Cordoba, J. J., FernandezGarayzabal, J., Garcia, J.-L., Cal, J., Hippe, H. \& Farrow, J. A. E. (1994). The phylogeny of the genus Clostridium: proposal of five new genera and eleven new species combinations. Int J Syst Bacteriol 44, 812-826.

Farrow, J. A. E., Lawson, P. A., Hippe, H., Gauglitz, U. \& Collins, M. D. (1995). Phylogenetic evidence that the Gram-negative nonsporulating bacterium Tissierella (Bacteroides) praeacuta is a member of the Clostridium subphylum of the Gram-positive bacteria and description of Tissierella creatinini sp. nov. Int J Syst Bacteriol 45, 436-440.

Gerhardt, P., Murray, R. G. E., Costilow, R. N., Nester, E. W., Wood, W. A., Krieg, N. R. \& Phillips, G. B. (editors) (1994). Methods for General and Molecular Bacteriology. Washington, DC: American Society for Microbiology.

Hippe, H., Andreesen, J. R. \& Gottschalk, G. (1992). The genus Clostridium - nonmedical. In The Prokaryotes, 2nd edn, vol. 2, pp. 1800-1866. Edited by A. Balows, H. G. Trüper, M. Dworkin, W. Harder \& K. H. Schleifer. New York: Springer.

Hoover, R. B., Pikuta, E. V., Marsic, D. \& Ng, J. (2002). Anaerobic psychrophiles from Alaska, Antarctica, and Patagonia: implications to possible life on Mars and Europa. In Instruments, Methods, and Missions for Astrobiology IV (SPIE Proceedings Series, vol. 4495), pp. 313-324. Edited by R. B. Hoover, G. V. Levin, R. R. Paepe, A. Yu. Rozanov. Bellingham, WA: SPIE.

Hoover, R. B., Pikuta, E. V., Bej, A. K., Marsic, D., Whitman, W. B., Tang, J. \& Krader, P. (2003). Spirochaeta americana sp. nov., a new haloalkaliphilic, obligately anaerobic spirochete isolated from soda Mono Lake in California. Int J Syst Evol Microbiol 53, 815-821.

Jukes, T. H. \& Cantor, C. R. (1969). Evolution of protein molecules. In Mammalian Protein Metabolism, vol. 3, pp. 21-132. Edited by H. N. Munro. New York: Academic Press.

Kevbrin, V. V., Zhilina, T. N., Rainey, F. A. \& Zavarzin, G. A. (1998). Tindallia magadii gen. nov., sp. nov.: an alkaliphilic anaerobic ammonifier from soda lake deposits. Curr Microbiol 37, 94-100.

Klouche, N., Fardeau, M. L., Lascourreges, J. F., Cayol, J. L., Hacene, H., Thomas, P. \& Magot, M. (2007). Geosporobacter subterraneus gen. nov., sp. nov., a spore-forming bacterium isolated from a deep subsurface aquifer. Int J Syst Evol Microbiol 57, 1757-1761.

Love, D. N., Jones, R. F. \& Bailey, M. (1979). Clostridium villosum sp. nov. from subcutaneous abscesses in cats. Int J Syst Bacteriol 29, 241244.

Mesbah, M., Premachandran, U. \& Whitman, W. (1989). Precise measurement of the $\mathrm{G}+\mathrm{C}$ content of deoxyribonucleic acid by highperformance liquid chromatography. Int J Syst Bacteriol 39, 159-167.

Pikuta, E. V. \& Hoover, R. B. (2003). Psychrophiles and astrobiology: microbial life of frozen worlds. In Instruments, Methods, and Missions for Astrobiology VI (SPIE Proceedings Series, vol. 4939), pp. 103-116. Edited by R. B. Hoover, A. Yu. Rozanov \& J. H. Lipps. Bellingham, WA: SPIE.

Pikuta, E. V. \& Hoover, R. B. (2004). Growth of the facultative anaerobes from Antarctica, Alaska, and Patagonia at low temperatures. In Instruments, Methods, and Missions for Astrobiology VIII (SPIE Proceedings Series, vol. 5555), pp. 160-191. Edited by R. B. Hoover, G. V. Levin \& A. Yu. Rozanov. Bellingham, WA: SPIE.

Pikuta, E. V., Hoover, R. B., Marsic, D., Bej, A. K., Tang, J., Cleland, D. \& Krader, P. (2003). Psychrotolerant anaerobic bacteria from Patagonia and the permafrost tunnel of Fox, Alaska. In Abstracts of 
the 103rd General Meeting of the American Society for Microbiology, p. 351, 18-22 May 2003, Washington, DC.

Pikuta, E. V., Hoover, R. B., Bej, A. K., Marsic, D., Whitman, W. B., Krader, P. E. \& Tang, J. (2006). Trichococcus patagoniensis sp. nov., a facultative anaerobe that grows at $-5{ }^{\circ} \mathrm{C}$, isolated from penguin guano in Chilean Patagonia. Int J Syst Evol Microbiol 56, 2055-2062.

Ravot, G., Magot, M., Fardeau, M.-L., Patel, B. K. C., Thomas, P., Garcia, J.-L. \& Ollivier, B. (1999). Fusibacter paucivorans gen. nov., sp. nov., an anaerobic, thiosulfate-reducing bacterium from oil-producing well. Int J Syst Bacteriol 49, 1141-1147.

Saitou, N. \& Nei, M. (1987). The neighbor-joining method: a new method for reconstructing phylogenetic trees. Mol Biol Evol 4, 406-425.

Stams, A. J. M. \& Hansen, T. A. (1984). Fermentation of glutamate and other compounds by Acidaminobacter hydrogenoformans gen. nov. sp. nov., an obligate anaerobe isolated from black mud. Studies with pure cultures and mixed cultures with sulfate-reducing and methanogenic bacteria. Arch Microbiol 137, 329-337.
Takai, K., Moser, D. P., Onstott, T. C., Spoelstra, N., Pfiffner, S. M., Dohnalkova, A. \& Fredrickson, J. K. (2001). Alkaliphilus transvaalensis gen. nov., sp. nov., an extremely alkaliphilic bacterium isolated from a deep South African gold mine. Int J Syst Evol Microbiol 51, 1245-1256.

Tamura, K., Dudley, J., Nei, M. \& Kumar, S. (2007). MEGA4: molecular evolutionary genetics analysis (MEGA) software version 4.0. Mol Biol Evol 24, 1596-1599.

Thompson, J. D., Higgins, D. G. \& Gibson, T. J. (1994). Clustal W: improving the sensitivity of progressive multiple sequence alignment through sequence weighting, position-specific gap penalties and weight matrix choice. Nucleic Acids Res 22, 4673-4680.

Wolin, E. A., Wolin, M. J. \& Wolfe, R. S. (1963). Formation of methane by bacterial extracts. J Biol Chem 238, 2882-2886.

Zhilina, T. N., Detkova, E. N., Rainey, F. A., Osipov, G. A., Lysenko, A. M., Kostrikina, N. A. \& Zavarzin, G. A. (1998). Natronoincola histidinovorans gen. nov., sp. nov., a new alkaliphilic acetogenic anaerobe. Curr Microbiol 37, 177-185. 